\title{
Role of galectins in lung cancer (Review)
}

\author{
WEI-AN CHANG ${ }^{1,2}$, MING-JU TSAI ${ }^{2,3}$, PO-LIN KUO ${ }^{1}$ and JEN-YU HUNG ${ }^{2,3}$ \\ ${ }^{1}$ Graduate Institute of Clinical Medicine, College of Medicine, Kaohsiung Medical University; ${ }^{2}$ Division of Pulmonary and \\ Critical Care Medicine, Department of Internal Medicine, Kaohsiung Medical University Hospital; ${ }^{3}$ Department of Internal \\ Medicine, School of Medicine, College of Medicine, Kaohsiung Medical University, Kaohsiung 807, Taiwan, R.O.C.
}

Received August 17, 2016; Accepted July 7, 2017

DOI: $10.3892 / \mathrm{ol} .2017 .6882$

\begin{abstract}
Lung cancer is the leading cause of cancer-associated mortality worldwide and is also associated with a poor prognosis. As in numerous other types of cancer, galectins have been demonstrated to be involved in the progression of lung cancer. Galectins belong to a superfamily of lectins, which are carbohydrate-binding proteins. There are at least 15 members in the galectin family, however, only galectin- $1,-2,-3,-4,-7$, $-8,-9,-10,-12$, and -13 are found in humans. Galectins are able to mediate interactions between cells, including homotypic and heterotypic interactions; they also facilitate the bindings between cells and extracellular matrix components. These cell-cell and cell-matrix interactions, as well as the galectin signaling on the cell surface, are able to modulate signaling pathways and thereby influence cellular functions and behaviors. Galectin-1, -3, -4, -7, -8 and -9 are associated with lung cancer. These galectins are associated with tumor invasion, migration, metastasis and progression, and may serve important roles in the tumor microenvironment of lung cancer. The majority of galectins are associated with the progression of lung cancer, with the exception of galectin-9, which is associated with enhanced anticancer immunity. Therefore, galectins may be potential targets for developing novel lung cancer therapies.
\end{abstract}

\section{Contents}

1. Introduction

2. Functions of galectins

3. Roles of galectins in cancer

4. Roles of galectins in lung cancer

5. Conclusions and future perspectives

Correspondence to: Dr Jen-Yu Hung, Division of Pulmonary and Critical Care Medicine, Department of Internal Medicine, Kaohsiung Medical University Hospital, 16ES, 100 Tz-You 1st Road, Kaohsiung 807, Taiwan, R.O.C.

E-mail: jenyuhung@gmail.com

Key words: lung cancer, galectin, tumor microenvironment, malignancy

\section{Introduction}

Galectins, whose name was proposed in 1994 from their description as $\beta$-galactoside-binding lectins, are a family of animal carbohydrate-binding proteins that agglutinate cells (1-3). Since their initial isolation from animals, including electric eels, chicks and calves in the 1970s, at least 15 members of this family have been identified. Galectins were systematically renamed in 1994, primarily based on the order in which they were identified (4).

Galectins perform their biological functions principally through interactions with specific glycoconjugates. Galectins possess high affinity for $\mathrm{N}$-acetyllactosamine sequences through their highly conserved carbohydrate recognition domains (CRDs) (5). All galectins possess at least one CRD.

Galectins are classified by the number and structure of CRDs into three major groups: Prototypical galectins, tandem-repeat galectins and chimeric galectins (Fig. 1) $(1,4,6,7)$. The prototypical galectins, including galectins- $1,-2,-5,-7,-10,-11,-13$, -14 and -15 , contain two identical CRDs to form homodimers and are therefore occasionally known as dimeric galectins. Tandem-repeat galectins, including galectins- $4,-6,-8,-9$ and -12 , are characterized by containing at least two distinct CRDs, connected by linker domains, within a single polypeptide. Galectin-3 is the only chimeric galectin identified in vertebrates; it contains a single CRD and a large amino-terminal domain, which contributes to self-aggregation, resulting in its common appearance of multiple identical subunits (6).

Not all galectins are present in humans: Only galectin-1, $-2,-3,-4,-7,-8,-9,-10,-12$, and -13 (6). Galectin-5 and galectin- 6 are present in rodents, and galectin-11, -14 , and -15 are observed in sheep and goats $(4,6)$. Notably, a number of galectin transcripts may be differentially spliced in certain types of tissue to generate a variety of isoforms. For example, at least seven different mRNAs encoding human galectin-8 have been identified, some in prototypical isoforms and others in tandem-repeat isoforms; these isoforms may be expressed differentially in various tissues (4). Three isoforms of galectin-9 with variations in their linker domain length have been identified (4).

\section{Functions of galectins}

Galectins are able to mediate certain interactions between cells, including homotypic and heterotypic interactions; they 
also facilitate the bindings between cells and extracellular matrix components. These cell-cell and cell-matrix interactions, as well as galectin signaling on the cell surface, are able to modulate signaling pathways and thereby influence cellular functions and behaviors (Fig. 2) (7-9).

Roles of galectins in apoptosis. Galectin-1, -2, -3, -7, -8, -9, and -12 are able to induce apoptosis in certain types of blood cells (10). Galectin-1-induced apoptosis involves interactions between $\mathrm{T}$ cells and surface glycoproteins, associated with cluster of differentiation (CD)7, CD29 and CD43. The apoptosis induced by galectin-3 is associated with CD71 and CD45 (11), and the overexpression of intracellular galectin-3 may exhibit anti-apoptotic activity (12).

Roles of galectins in development. Galectins have also been demonstrated to be involved in animal development. For example, galectin-3 ablation in mice is associated with decreased mast cell function, as well as fatty liver disease, liver fibrosis, age-dependent glomerular lesions and lung fibrosis (13). Galectin-1 is involved in pathfinding and axon regeneration, and its ablation in mice is associated with a decreased sensitivity response to noxious thermal stimuli. As such, galectin-1 may be associated with anatomical and functional deficits in the development of neurons (14). Additionally, galectins are also involved in post-developmental processes, including immune regulation (10).

Roles of galectins in inflammation and immune responses. The regulation of inflammatory and immune responses is a major function of galectins. Numerous types of blood cells express galectins, including activated $\mathrm{T}$ and $\mathrm{B}$ cells, regulatory $\mathrm{T}$ cells, dendritic cells, mast cells, monocytes/macrophages, eosinophils and neutrophils. Depending on various inflammatory stimuli, the microenvironment and the target cells, galectins are associated with pro- or anti-inflammatory responses (10). In a study of autoimmune retinal disease, galectin-1 was demonstrated to be able to induce anti-inflammatory cytokines, including interleukin (IL)-5 and IL-10, and to suppress the expression of interferon $\gamma$, ultimately suppressing the inflammatory response (15). Additionally, galectin-3 serves an important role in the activation of T cells, potentially associated with its interaction with poly- $\mathrm{N}$-acetyllactosamine-containing $\mathrm{N}$-glycans on T-cell receptors (16). In certain immune cells, particularly eosinophils, the addition of galectin-3 leads to the suppressed production of IL-5 by downregulation of the expression of the IL-5 gene (17). Other blood cells, including mast cells, neutrophils, lymphocytes and monocytes, are activated by galectin-3 (18). In the function of mast cells, endogenous galectin-3 is involved in the phagocytosis of macrophages and the promotion of inflammation in the airway (19).

\section{Roles of galectins in cancer}

Galectins contribute to carcinogenesis and cancer progression. Protein-glycan interactions are important in the progression of cancer, including being involved in carcinogenesis, proliferation, metastasis, angiogenesis and the immune response (20). Galectins are modulated during the differentiation of cells and the development of organs; errors in this modulation occur in a number of physiological and pathological conditions (21). Additionally, galectins serve a role in tumor transformation and survival, having been demonstrated to be involved in tumorigenesis, the regulation of apoptosis, tumor invasion and angiogenesis, the adhesion of cells during metastasis and the tumor immune response (21). Each galectin exhibits distinct effects in different cancer types. Previous studies have demonstrated that galectin-1 and -3 promote pro-tumorigenic activity by binding to the ligands of cancer cells (22), potentially promoting the progression of distinct types of cancer (6). These pro-tumorigenic activities may include affecting tumor growth, metastasis and angiogenesis, and the promotion of radio- and chemo-resistance, while galactin-1 and -3 also suppress $\mathrm{T}$ cell function to affect the tumor microenvironment (6). Other galectins also contribute to the progression of various types of cancer, for example galectin-7 promotes metastatic potential and apoptosis-resistance in breast cancer (23), and is overexpressed in esophageal squamous cell carcinoma (24). Notably, increased galectin-7 expression is associated with improved outcome following radiotherapy for cervical cancer (25) and serves a tumor-suppressive role in gastric cancer (26). In addition, galectin-4 is important in the metastatic potential of lung adenocarcinoma (27) and may also prevent detachment of pancreatic cancer cells through its adhesion molecule-like function (11). Galectin-9 is a good prognostic factor in breast cancer due to its anti-metastatic potential (12). Galectin-2, -4 and -8 may increase adhesion of colon cancer cells to endothelial cells, enhancing the metastasis of colon cancer (28).

Galectin expression in cancerous tissues. Expression of galectins is observed in numerous types of cancer tissue, including cancer of the digestive, reproductive, respiratory, neural, urinary and hematological systems (7). The galectins most extensively studied in oncology are galectin-1, -3, -4, -7, -8 and -9 , with numerous studies comparing the expression levels of galectins between normal and malignant tissues. Notably, each galectin may exhibit increased expression in distinct types of cancer, but decreased expression in others; similarly, a specific cancer may have increased expression levels of certain galectins, but decreased expression levels of others (7). For example, galectin-1 expression is increased in the majority of cancer types $(7,29)$, although certain studies have revealed decreased galectin-1 expression in malignant tissues of bladder cancer (30), uterine cancer (31) and head and neck squamous cell carcinoma (13), whereas other studies have observed increased galectin-1 expression in these same types of cancer (14-16). The expression of galectin-3 is also heterogeneous, with increased expression levels identified in thyroid cancer, lung cancer, and the majority of digestive tract and urinary system tumors, whereas decreased expression levels have been observed in reproductive system tumors (7). Studying the expression of galectin- 8 and -9 in cancer is complicated due to extensive splicing of their mRNA transcripts, generating various isoforms (7). As a result, they may exhibit decreased mRNA levels (17), but increased protein levels (18).

Galectin expression and cancer prognosis. Much effort has been made to determine the association between galectin 


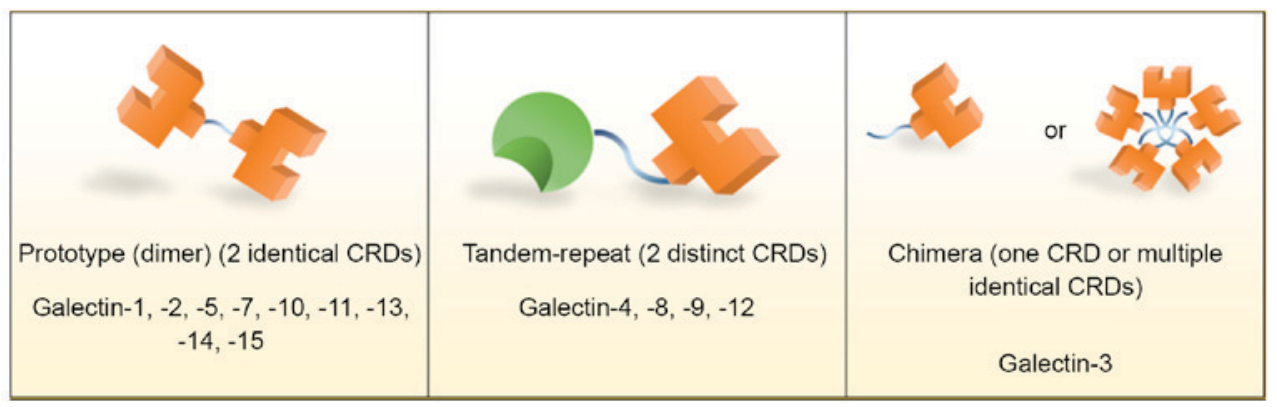

Figure 1. Classification of galectins into prototypical (dimeric), tandem-repeat and chimeric galectins. Prototypical (dimeric) galectins possess two identical CRDs. Tandem-repeat galectins possess two distinct CRDs. Chimeric galectins possess a single CRD, and may aggregate to form its common appearance with multiple identical CRDs. CRD, carbohydrate-recognition domains.

expression level and cancer prognosis. Irrespective of the cancer type, increased expression of galectin-1 is generally associated with poor overall and disease-free survival rates (7). By contrast, studies of galectin-3 for the prediction of cancer prognosis revealed various results, mostly depending on the cancer types. Increased expression of galectin-3 in brain cancer (32), acute myeloid leukemia (33) and colorectal cancer (34) is associated with poorer overall survival times and rates, while increased expression of galectin-3 is associated with improved survival rate in gastric cancer (19). In addition to predicting cancer prognosis, the levels of galectins are also associated with the stages and grades in different cancer types. A positive correlation between the expression level of galectin-1 and cancer stage has been observed in gastric cancer (35), ovarian cancer (36) and chronic lymphocytic leukemia (37). In colon cancer, the expression of galectin-3 has proven to be correlated with the stage of colon cancer (38). A positive correlation between the expression of galectin- 3 and tumor grade has also been reported (39).

Galectins as diagnostic biomarkers. As aforementioned, cancer typically exhibits altered galectin expression. Since galectins are secreted, their circulating levels may be taken as useful biomarkers to predict the presence of malignancies. For example, a previous study revealed that serum galectin-1 levels were increased in patients with lung cancer compared with healthy subjects, as well as increased mRNA expression levels of galectin-1 in tumor sections compared with non-tumor sections (40). The circulating levels and tissue levels of galectin- 1 and -3 are increased in thyroid cancer patients (41), with similar results observed in clinical cases such as that for galectin-3 expression in melanoma (42) and galectin- 8 expression in breast cancer (28). However, a study of thyroid tumors has demonstrated a dissociation between circulating galectin levels and tissue galectin levels (43). These observed discrepancies in the literature may be due to a number of reasons, including the non-classical secretion pathways of galectins and the abnormal activity of cellular signaling pathways in tumor cells (7).

Galectins as biomarkers for prognosis and treatment response. Circulating galectins may also be useful biomarkers for predicting cancer prognosis and treatment response. For example, in Hodgkin's lymphoma, the circulating galectin-1 expression level is well correlated with tumor burden, clinical

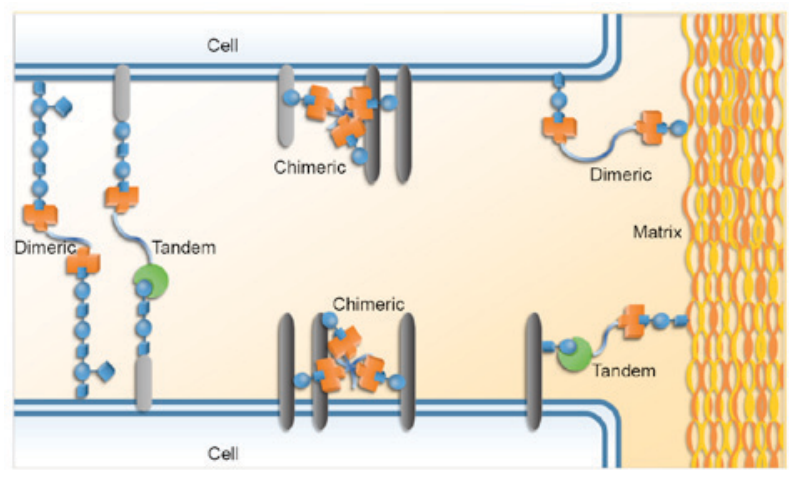

Figure 2. Galectins are able to mediate cell-cell and cell-matrix interactions, and thereby modulate signaling pathways and influence cellular behavior.

staging and other prognostic markers (44). Similarly, circulating galectin-3 expression level is a valuable prognostic marker in patients with advanced melanoma (45). In breast and gastrointestinal cancer, serum galectin-3 expression level is significantly different between patients with metastatic and non-metastatic diseases (46). In colon cancer, serum galectin-3 and galectin- 4 expression levels are distinct between patients with metastatic and non-metastatic disease (47).

Serum galectins are also useful for monitoring therapeutic response in patients with cancer. In a previous study, serum galectin-3 expression level decreased significantly following surgery in patients with pancreatic cancer (48). Serum levels of galectin-1, -3 and -4 were increased in patients with colorectal cancer, and their serum levels of galectin- 1 and -4 decreased significantly following curative surgery (49). In head and neck squamous cell carcinoma, galectin-1 and galectin-3 also decreased following surgical and chemotherapeutic treatments (50).

Taken together, circulating galectin levels may be potential biomarkers for detecting cancer, and for predicting disease prognosis and therapeutic efficacy (7).

\section{Roles of galectins in lung cancer}

Overview. Lung cancer is one of the most common types of cancer, as well as being the leading cause of cancer-associated mortality worldwide $(51,52)$. Lung cancer is classified as either non-small cell lung cancer (NSCLC) or SCLC. NSCLC is traditionally classified into squamous cell carcinoma, large 
Table I. Effects of each galectin identified to affect lung cancer progression.

\begin{tabular}{|c|c|c|}
\hline Galectin & Type & Effects in lung cancer (Reference) \\
\hline Galectin-1 & Dimeric & $\begin{array}{l}\text { Galectin-1/interleukin-10 functional axis may be an important regulator in lung } \\
\text { cancer-mediated immune suppression ( } 40) \text {. } \\
\text { Upregulates and promotes migration and invasion (54). } \\
\text { Lymph node metastasis of lung cancer ( } 54) \text {. } \\
\text { Mediates tumor progression and chemoresistance of non-small cell lung cancer (55). }\end{array}$ \\
\hline Galectin-3 & Chimeric & $\begin{array}{l}\text { Enhances lung cancer adhesion to extracellular matrix components, cell motility and } \\
\text { in vitro invasiveness (56). } \\
\text { Promotes cancer stem cell formation, chemoresistance, tumorigenicity, tumor } \\
\text { initiation and sphere-forming capacity (57). } \\
\text { Promotes epidermal growth factor receptor activation and enhances lung cancer } \\
\text { stemness through the EGFR/c-Myc/Sox } 2 \text { axis (58). }\end{array}$ \\
\hline Galectin-4 & Tandem & $\begin{array}{l}\text { Expressed in the cytoplasm, nucleus and membrane of lung adenocarcinomas (27). } \\
\text { May be an independent predictor for lymph node metastasis (27). }\end{array}$ \\
\hline Galectin-7 & Dimeric & May be associated with the metastasis of other types of cancer to the lung (59). \\
\hline Galectin-8 & Tandem & Associated with metastatic progression of lung cancer (60). \\
\hline Galectin-9 & Tandem & $\begin{array}{l}\text { Suppresses pulmonary metastasis by tumor cell, tumor attachment and } \\
\text { tumor invasion ( } 61) \text {. } \\
\text { Promotes activation of natural killer cells (62). }\end{array}$ \\
\hline
\end{tabular}

cell carcinoma, adenocarcinoma and other less frequently observed cell types (53). Although NSCLC is often attributed to cigarette smoking, adenocarcinoma is often observed in individuals who have never smoked. Numerous compounds and molecular mechanisms are involved in the formation and progression of lung cancer; as for other cancer types, galectins serve important roles in these processes (6). Previous studies have demonstrated that galectin-1, $-3,-4,-7,-8$ and -9 are associated with lung cancer (Table I) $(27,40,54-62)$, whereas the roles of galectin- $2,5,-6,-10,-11,-12,-13,-14$ and -15 in lung cancer are, to the best of our knowledge, yet to be investigated.

Galectin-1. Galectin-1 was the first identified galectin and it is overexpressed in numerous types of cancer, including lymphoma, astrocytoma and melanoma, as well as oral, colon, liver, pancreatic, bladder and ovarian cancers (63). A previous study demonstrated that the galectin-1/IL-10 functional axis may be an important regulator in lung cancer-mediated immune suppression (40). Galectin-1 is an immune modulator of the development of monocytes, which is controlled via IL-10 and granulocyte-colony stimulating factor (64). Galectin-1 is overexpressed in highly-invasive lung cancer cell lines and is important in promoting lung cancer cell invasion and migration (5). Galectin-1 derived from lung cancer modifies dendritic cells to produce mitogenic and pro-invasive factors, which subsequently promote tumorigenic potentiation of dendritic cells by expressing heparin-binding epidermal growth factor (EGF)-like growth factor (65). Galectin-1 also possesses the potential to be a prognostic marker in early-stage NSCLC (66). Patients with tumors exhibiting increased galectin-1 expression experience poorer clinical outcomes (67). Galectin-1 is upregulated in CD133+ lung adenocarcinoma cells, occasionally designated as cancer stem cells, which promotes the growth of $\mathrm{CD}_{133^{+}}$lung

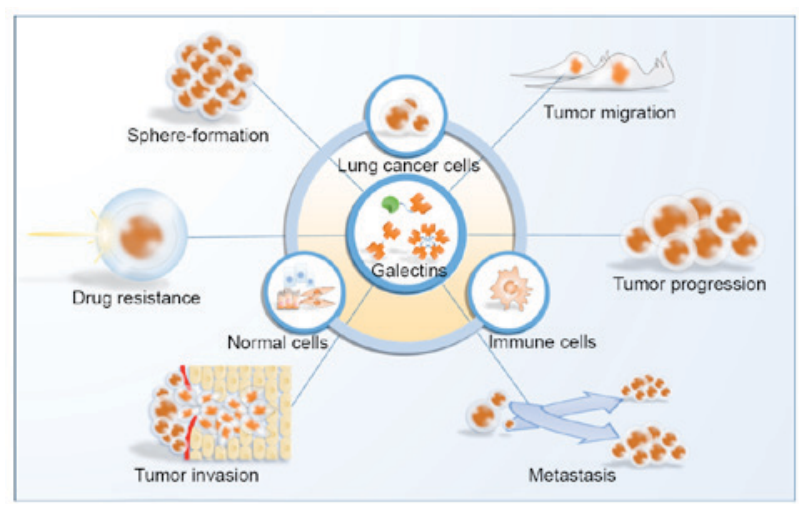

Figure 3. Roles of galectins in lung cancer. Galectins affect the progression of lung cancer in multiple aspects, including tumor migration, tumor progression, metastasis, tumor invasion, drug resistance, sphere-formation and the interactions between cells in the tumor microenvironment.

adenocarcinoma (54). Serum galectin-1 level is positively correlated to the stage and prognosis of patients with lung adenocarcinoma (54), and has also been revealed to mediate the tumor progression and chemo-resistance of NSCLCs by activation of p38 mitogen-activated protein kinase, extracellular signal-regulated kinase and prostaglandin-endoperoxidase synthase 2 (55). In NSCLC, tumor-associated galectin-1 secretion mediates radiotherapy-associated systemic lymphopenia and may affect tumor progression (68).

Galectin-3. The role of galectin-3 in lung cancer has also been extensively studied. Expression of galectin-3 has been observed extensively in normal lung cells, including bronchial epithelial cells, chondrocytes of the bronchial cartilage, pneumocytes of the alveolar wall, alveolar macrophages and interstitial fibroblasts (69). NSCLC generally possesses 
significantly increased galectin-3 expression compared with SCLC (3). Galectin-3 was found in extracellular and intracellular compartments of NSCLC; in squamous cell carcinoma, galectin-3 was primarily identified in the cytoplasm, whereas it was observed in the cytoplasm and nucleus in adenocarcinoma (3). Overexpression of galectin-3 in DLKP lung cancer cells enhances their adhesion to extracellular matrix components, increasing cell motility and invasiveness (56). Overexpression of galectin-3 in A549 cells promotes their sphere-forming capacity (a character of cancer stem cells), and suppression of galectin-3 in H1299 cells in vitro decreases the expression of stemness-associated genes, their sphere-forming capacity, tumorigenicity, chemo-resistance; in vivo, suppression of galectin-3 in H1299 cells also decreases tumor-initiating capacity in NOD/SCID mice (57). In Lewis lung carcinoma-bearing mice, increased expression of galectin-3 may promote the migration of myeloid-derived suppressor cells to the tumor microenvironment following exposure to cisplatin, contributing to the immuno-suppressive status of the tumor microenvironment (70). Galectin-3 may also be used as a prognostic marker; nuclear galectin-3 expression has been revealed as an independent predictive factor for the recurrence of NSCLC (55). Detection of galectin-3 and CD82 may be associated with the initiation, development and metastasis of NSCLC (71). Galectin-3 has also been demonstrated to promote EGF receptor activation in lung cancer, leading to the upregulation of sex determining region Y-box 2 expression and sphere formation (58).

Galectin-4. In contrast to its almost exclusive distribution in the cytoplasm of breast cancer and colon cancer cells, galectin- 4 is extensively detected in the cytoplasm, nucleus and membranes of lung adenocarcinoma (72). In lung adenocarcinoma, the expression of galectin- 4 is associated with clinicopathological variables of disease progression, including tumor size, nodal status, pleural or venous invasion, and tumor-node-metastasis staging, and may be an independent predictor for lymph node metastasis of intermediate power (27). Unlike gastric carcinoid tumors, which exhibited increased galectin- 4 expression, a limited number of pulmonary carcinoids possessed decreased galectin-4 expression (73).

Galectin-7. With regard to cancer progression, galectin-7 has distinct functions in various types of cancer. Galectin-7 has been revealed to be associated with the sensitivity of human cervical carcinoma cells to chemotherapy-induced apoptosis (74). In melanoma, galectin-7 has been found in the primary site and the lung metastasis site (75). Although no convincing evidence has demonstrated that galectin-7 is directly associated with lung cancer, it may be associated with cancer metastasis to the lung; for example, it has been demonstrated to promote the bone and lung metastasis of breast cancer (59).

Galectin-8. Human galectin-8, encoded from the lectin galactoside-binding soluble 8 gene, has a variety of isoforms as a result of alternative splicing. Galectin- 8 was initially isolated from the prostate [prostate carcinoma tumor antigen (PCTA)-1] and lung [Po66 carbohydrate-binding protein (Po66-CBP)] (76-78). PCTA-1 and Po66-CBP share 98.7\% of their amino acid sequence (79). Galetin-8 is widely expressed in normal tissue, as well as in tumor tissue (79); however, it is overexpressed in squamous cell carcinoma, with its expression level associated with the degree of tumor differentiation $(76,80)$. Using cell-extracellular matrix microarrays, galectin-8, in combination with fibronectin, has been demonstrated to be associated with the metastatic progression of lung adenocarcinoma (60). The marked difference in galectin- 8 expression levels between lung cancer cells and normal lung tissues may provide the opportunity to use monoclonal antibodies for preventing and treating lung cancer $(79,81)$.

Galectin-9. A limited number of studies have investigated the role of galectin-9 in lung cancer, however, it has been widely studied in the field of immunity and inflammation. Increased cytoplasmic galectin-9 expression in tumor cells may suppress pulmonary metastasis and recurrence of malignant melanoma and breast cancer, which may be associated with the suppressive effect of galectin-9 on the attachment and invasion of tumor cells (61). Galectin-9 is also important in anticancer immunity. For example, galectin- 9 has been revealed to increase T-cell immunoglobulin and mucin-domain containing (TIM) $-3^{+}$dendritic cells and $\mathrm{CD} 8^{+}$cytotoxic $\mathrm{T}$ cells, and to enhance anticancer immunity through its interaction with TIM-3 in MethA cell-bearing mice (82). In a study using Lewis lung carcinoma cell-bearing mice, galectin-9 was demonstrated to induce macrophage differentiation into plasmacytoid dendritic cell-like macrophages, which may augment the activation of NK cells that prolong the survival of tumor-bearing mice (62).

\section{Conclusions and future perspectives}

Each galectin possesses specific functions and is observed at distinct locations. Galectins serve important roles in cell survival, cellular proliferation, adhesion and migration (83), and they also participate in cell-cell and cell-matrix interactions (84). These characteristics may suggest that galectins may be an important component of the tumor microenvironment. The tumor microenvironment has been recognized as an important contributor to cancer progression, chemo-resistance (85), invasion and metastasis (86). The majority of galectins have been revealed to be associated with lung cancer, including galectin- $1,-3,-4,-7$ and -8 , which are associated with the progression of lung cancer, while galectin-9 may decrease metastasis and enhance anticancer immunity. However, with the exception of galectin-1 and -3 , the roles of galectins in lung cancer are not fully understood and require further investigation. The roles of galectins in lung cancer are much more complicated than suggested thus far, since numerous types of cell, particularly immune cells, in the tumor microenvironment may participate in their interactions (Fig. 3). Future studies to improve our understanding of the roles of galectins in the carcinogenesis, progression, invasion, metastasis and chemo-resistance of lung cancer are required in order to identify potential therapeutic targets for novel anticancer treatments. 


\section{Acknowledgements}

The present study was supported by the Ministry of Science and Technology (grant no. MOST 104-2320-B-037-014-MY3) and the Kaohsiung Medical University 'Aim for the Top Journals Grant' (grant no. KMU-DT106005).

\section{References}

1. Barondes SH, Cooper DN, Gitt MA and Leffler H: Galectins, Structure and function of a large family of animal lectins. J Biol Chem 269: 20807-20810, 1994.

2. Powell JT and Whitney PL: Postnatal development of rat lung. Changes in lung lectin, elastin, acetylcholinesterase and other enzymes. Biochem J 188: 1-8, 1980.

3. Buttery R, Monaghan H, Salter DM and Sethi T: Galectin-3: Differential expression between small-cell and non-small-cell lung cancer. Histopathology 44: 339-344, 2004.

4. Cummings RD and Liu FT: Chapter 33 Galectins. In: Essentials of Glycobiology. 2nd edition. Varki A, Cummings RD, Esko JD, et al (eds). Cold Spring Harbor Laboratory Press, La Jolla, California, 2009.

5. Hsu YL, Wu CY, Hung JY, Lin YS, Huang MS and Kuo PL: Galectin-1 promotes lung cancer tumor metastasis by potentiating integrin $\alpha 6 \beta 4$ and Notch1/Jagged 2 signaling pathway. Carcinogenesis 34: 1370-1381, 2013.

6. Ebrahim AH, Alalawi Z, Mirandola L, Rakhshanda R, Dahlbeck S, Nguyen D, Jenkins M, Grizzi F, Cobos E, Figueroa JA and Chiriva-Internati M: Galectins in cancer: Carcinogenesis, diagnosis and therapy. Ann Transl Med 2: 88, 2014.

7. Thijssen VL, Heusschen R, Caers J and Griffioen AW: Galectin expression in cancer diagnosis and prognosis: A systematic review. Biochim Biophys Acta 1855: 235-247, 2015.

8. Elola MT, Wolfenstein-Todel C, Troncoso MF, Vasta GR and Rabinovich GA: Galectins: Matricellular glycan-binding proteins linking cell adhesion, migration and survival. Cell Mol Life Sci 64: 1679-1700, 2007.

9. Compagno D, Jaworski FM, Gentilini L, Contrufo G, González Pérez I, Elola MT, Pregi N, Rabinovich GA and Laderach DJ Galectins: Major signaling modulators inside and outside the cell. Curr Mol Med 14: 630-651, 2014.

10. Varki A, Cummings RD, Esko JD, Freeze HH, Stanley P, Bertozzi CR, Hart GW, and Etzler ME: Essentials of Glycobiology, 2nd edition (eds). Cold Spring Harbor Laboratory Press, Cold Spring Harbor (NY), 2019.

11. Belo AI, van der Sar AM, Tefsen B and van Die I: Galectin-4 reduces migration and metastasis formation of pancreatic cancer cells. PLoS One 8: e65957, 2013.

12. Irie A, Yamauchi A, Kontani K, Kihara M, Liu D, Shirato Y, Seki M, Nishi N, Nakamura T, Yokomise H and Hirashima M: Galectin-9 as a prognostic factor with antimetastatic potential in breast cancer. Clin Cancer Res 11: 2962-2968, 2005

13. Choufani G, Nagy N, Saussez S, Marchant H, Bisschop P, Burchert M, Danguy A, Louryan S, Salmon I, Gabius HJ, et al: The levels of expression of galectin-1, galectin-3, and the Thomsen-Friedenreich antigen and their binding sites decrease as clinical aggressiveness increases in head and neck cancers. Cancer 86: 2353-2363, 1999.

14. Gillenwater A, Xu XC, el-Naggar AK, Clayman GL and Lotan R: Expression of galectins in head and neck squamous cell carcinoma. Head Neck 18: 422-432, 1996.

15. Cindolo L, Benvenuto G, Salvatore P, Pero R, Salvatore G, Mirone V, Prezioso D, Altieri V, Bruni CB and Chiariotti L: Galectin-1 and galectin-3 expression in human bladder transitional-cell carcinomas. Int J Cancer 84: 39-43, 1999.

16. van den Brule FA, Buicu C, Berchuck A, Bast RC, Deprez M, Liu FT, Cooper DN, Pieters C, Sobel ME and Castronovo V: Expression of the 67-kD laminin receptor, galectin-1, and galectin-3 in advanced human uterine adenocarcinoma. Hum Pathol 27: 1185-1191, 1996.

17. Yang J, Zhu L, Cai Y, Suo J and Jin J: Role of downregulation of galectin-9 in the tumorigenesis of gastric cancer. Int J Oncol 45: 1313-1320, 2014.

18. Jiang J, Jin MS, Kong F, Cao D, Ma HX, Jia Z, Wang YP, Suo J and Cao X: Decreased galectin-9 and increased Tim-3 expression are related to poor prognosis in gastric cancer. PLoS One 8: e81799, 2013
19. Okada K, Shimura T, Suehiro T, Mochiki E and Kuwano H: Reduced galectin-3 expression is an indicator of unfavorable prognosis in gastric cancer. Anticancer Res 26: 1369-1376, 2006.

20. Pinho SS and Reis CA: Glycosylation in cancer: Mechanisms and clinical implications. Nat Rev Cancer 15: 540-555, 2015.

21. Liu FT and Rabinovich GA: Galectins as modulators of tumour progression. Nat Rev Cancer 5: 29-41, 2005.

22. Dimitroff CJ: Galectin-Binding O-glycosylations as regulators of malignancy. Cancer Res 75: 3195-3202, 2015.

23. Campion CG, Labrie M, Lavoie G and St-Pierre Y: Expression of galectin-7 is induced in breast cancer cells by mutant p53. PLoS One 8: e72468, 2013.

24. Zhu X, Ding M, Yu ML, Feng MX, Tan LJ and Zhao FK Identification of galectin-7 as a potential biomarker for esophageal squamous cell carcinoma by proteomic analysis. BMC Cancer 10: 290, 2010.

25. Tsai CJ, Sulman EP, Eifel PJ, Jhingran A, Allen PK, Deavers MT and Klopp AH: Galectin-7 levels predict radiation response in squamous cell carcinoma of the cervix. Gynecol Oncol 131: 645-649, 2013.

26. Kim SJ, Hwang JA, Ro JY, Lee YS and Chun KH: Galectin-7 is epigenetically-regulated tumor suppressor in gastric cancer. Oncotarget 4: 1461-1471, 2013.

27. Hayashi T, Saito T, Fujimura T, Hara K, Takamochi K, Mitani K, Mineki R, Kazuno S, Oh S, Ueno T, et al: Galectin-4, a novel predictor for lymph node metastasis in lung adenocarcinoma. PLoS One 8: e81883, 2013.

28. Barrow H, Guo X, Wandall HH, Pedersen JW, Fu B, Zhao Q, Chen C, Rhodes JM and Yu LG: Serum galectin-2, -4 and -8 are greatly increased in colon and breast cancer patients and promote cancer cell adhesion to blood vascular endothelium. Clin Cancer Res 17: 7035-7046, 2011.

29. Ding YM, Dong JH, Chen LL and Zhang HD: Increased expression of galectin-1 is associated with human oral squamous cell carcinoma development. Oncol Rep 21: 983-987, 2009.

30. Chung H, Kim B, Jung SH, Won KJ, Jiang X, Lee CK, Lim SD, Yang SK, Song KH and Kim HS: Does phosphorylation of cofilin affect the progression of human bladder cancer? BMC Cancer 13: $45,2013$.

31. Makino K, Kawamura K, Sato W, Kawamura N, Fujimoto T and Terada Y: Inhibition of uterine sarcoma cell growth through suppression of endogenous tyrosine kinase B signaling. PLoS One 7: e41049, 2012

32. Camby I, Belot N, Rorive S, Lefranc F, Maurage CA, Lahm H, Kaltner H, Hadari Y, Ruchoux MM, Brotchi J, et al: Galectins are differentially expressed in supratentorial pilocytic astrocytomas, astrocytomas, anaplastic astrocytomas and glioblastomas and significantly modulate tumor astrocyte migration. Brain Pathol 11: 12-26, 2001

33. Cheng CL, Hou HA, Lee MC, Liu CY, Jhuang JY, Lai YJ, Lin CW, Chen HY, Liu FT, Chou WC, et al: Higher bone marrow LGALS3 expression is an independent unfavorable prognostic factor for overall survival in patients with acute myeloid leukemia. Blood 121: 3172-3180, 2013.

34. Endo K, Kohnoe S, Tsujita E, Watanabe A, Nakashima H, Baba $\mathrm{H}$ and Maehara Y: Galectin-3 expression is a potent prognostic marker in colorectal cancer. Anticancer Res 25: 3117-3121, 2005

35. Chen J, Zhou SJ, Zhang Y, Zhang GQ, Zha TZ, Feng YZ and Zhang K: Clinicopathological and prognostic significance of galectin-1 and vascular endothelial growth factor expression in gastric cancer. World J Gastroenterol 19: 2073-2079, 2013.

36. Kim HJ, Jeon HK, Cho YJ, Park YA, Choi JJ, Do IG, Song SY, Lee YY, Choi CH, Kim TJ, et al: High galectin-1 expression correlates with poor prognosis and is involved in epithelial ovarian cancer proliferation and invasion. Eur J Cancer 48: 1914-1921, 2012.

37. Croci DO, Morande PE, Dergan-Dylon S, Borge M, Toscano MA, Stupirski JC, Bezares RF, Avalos JS, Narbaitz M, Gamberale R, et al: Nurse-like cells control the activity of chronic lymphocytic leukemia B cells via galectin-1. Leukemia 27: 1413-1416, 2013.

38. Nakamura $M$, Inufusa $H$, Adachi $T$, Aga $M$, Kurimoto $M$, Nakatani Y, Wakano T, Nakajima A, Hida JI, Miyake M, et al: Involvement of galectin-3 expression in colorectal cancer progression and metastasis. Int J Oncol 15: 143-148, 1999.

39. Strik HM, Deininger MH, Frank B, Schluesener HJ and Meyermann R: Galectin-3: Cellular distribution and correlation with WHO-grade in human gliomas. J Neurooncol 53: 13-20, 2001. 
40. Kuo PL, Hung JY, Huang SK, Chou SH, Cheng DE, Jong YJ, Hung CH, Yang CJ, Tsai YM, Hsu YL and Huang MS: Lung cancer-derived galectin-1 mediates dendritic cell anergy through inhibitor of DNA binding 3/IL-10 signaling pathway. J Immunol 186: 1521-1530, 2011.

41. Saussez S, Glinoer D, Chantrain G, Pattou F, Carnaille B, André S, Gabius HJ and Laurent G: Serum galectin-1 and galectin-3 levels in benign and malignant nodular thyroid disease. Thyroid 18: 705-712, 2008

42. Vereecken P, Zouaoui Boudjeltia K, Debray C, Awada A, Legssyer I, Sales F, Petein M, Vanhaeverbeek M, Ghanem G and Heenen $M$ : High serum galectin-3 in advanced melanoma: Preliminary results. Clin Exp Dermatol 31: 105-109, 2006.

43. Išić T, Savin S, Cvejić D, Marečko I, Tatić S, Havelka M and Paunović I: Serum Cyfra 21.1 and galectin-3 protein levels in relation to immunohistochemical cytokeratin 19 and galectin-3 expression in patients with thyroid tumors. J Cancer Res Clin Oncol 136: 1805-1812, 2010.

44. Ouyang J, Plütschow A, Pogge von Strandmann E, Reiners KS Ponader S, Rabinovich GA, Neuberg D, Engert A and Shipp MA: Galectin-1 serum levels reflect tumor burden and adverse clinical features in classical Hodgkin lymphoma. Blood 121: 3431-3433, 2013.

45. Vereecken P, Awada A, Suciu S, Castro G, Morandini R, Litynska A, Lienard D, Ezzedine K, Ghanem G and Heenen M: Evaluation of the prognostic significance of serum galectin-3 in American Joint Committee on Cancer stage III and stage IV melanoma patients. Melanoma Res 19: 316-320, 2009.

46. Iurisci I, Tinari N, Natoli C, Angelucci D, Cianchetti E and Iacobelli S: Concentrations of galectin-3 in the sera of normal controls and cancer patients. Clin Cancer Res 6: 1389-1393, 2000.

47. Barrow $\mathrm{H}$, Rhodes JM and Yu LG: Simultaneous determination of serum galectin-3 and -4 levels detects metastases in colorectal cancer patients. Cell Oncol (Dordr) 36: 9-13, 2013.

48. Gaida MM, Bach ST, Günther F, Baseras B, Tschaharganeh DF, Welsch T, Felix K, Bergmann F, Hänsch GM and Wente MN Expression of galectin-3 in pancreatic ductal adenocarcinoma. Pathol Oncol Res 18: 299-307, 2012

49. Watanabe M, Takemasa I, Kaneko N, Yokoyama Y, Matsuo E, Iwasa S, Mori M, Matsuura N, Monden M and Nishimura $\mathrm{O}$ : Clinical significance of circulating galectins as colorectal cancer markers. Oncol Rep 25: 1217-1226, 2011.

50. Saussez S, Lorfevre F, Lequeux T, Laurent G, Chantrain G Vertongen F, Toubeau G, Decaestecker C and Kiss R: The determination of the levels of circulating galectin-1 and -3 in HNSCC patients could be used to monitor tumor progression and/or responses to therapy. Oral Oncol 44: 86-93, 2008.

51. Siegel RL, Miller KD and Jemal A: Cancer statistics, 2015. CA Cancer J Clin 65: 5-29, 2015.

52. Tsai MJ, Yang CJ, Kung YT, Sheu CC, Shen YT, Chang PY, Huang MS and Chiu HC: Metformin decreases lung cancer risk in diabetic patients in a dose-dependent manner. Lung Cancer 86 : 137-143, 2014

53. Zhang Y, Wang H, Wang J, Bao L, Wang L, Huo J and Wang X: Global analysis of chromosome 1 genes among patients with lung adenocarcinoma, squamous carcinoma, large-cell carcinoma, small-cell carcinoma, or non-cancer. Cancer Metastasis Rev 34 249-264, 2015

54. Zhou X, Li D, Wang X, Zhang B, Zhu H and Zhao J: Galectin-1 is overexpressed in $\mathrm{CD} 133^{+}$human lung adenocarcinoma cells and promotes their growth and invasiveness. Oncotarget 6 : 3111-3122, 2015

55. Chung LY, Tang SJ, Sun GH, Chou TY, Yeh TS, Yu SL and Sun KH: Galectin-1 promotes lung cancer progression and chemoresistance by upregulating p38 MAPK, ERK and cyclooxygenase-2. Clin Cancer Res 18: 4037-4047, 2012.

56. O'Driscoll L, Linehan R, Liang YH, Joyce H, Oglesby I and Clynes M: Galectin-3 expression alters adhesion, motility and invasion in a lung cell line (DLKP), in vitro. Anticancer Res 22: 3117-3125, 2002

57. Chung LY, Tang SJ, Wu YC, Sun GH, Liu HY and Sun KH: Galectin-3 augments tumor initiating property and tumorigenicity of lung cancer through interaction with $\beta$-catenin. Oncotarget 6: 4936-4952, 2015.

58. Kuo HY, Hsu HT, Chen YC, Chang YW, Liu FT and Wu CW: Galectin-3 modulates the EGFR signalling-mediated regulation of Sox 2 expression via c-Myc in lung cancer. Glycobiology 26: $155-165,2016$
59. Demers M, Rose AA, Grosset AA, Biron-Pain K, Gaboury L, Siegel PM and St-Pierre Y: Overexpression of galectin-7, a myoepithelial cell marker, enhances spontaneous metastasis of breast cancer cells. Am J Pathol 176: 3023-3031, 2010.

60. Reticker-Flynn NE, Malta DF, Winslow MM, Lamar JM, Xu MJ, Underhill GH, Hynes RO, Jacks TE and Bhatia SN: A combinatorial extracellular matrix platform identifies cell-extracellular matrix interactions that correlate with metastasis. Nat Commun 3: 1122, 2012.

61. Nobumoto A, Nagahara K, Oomizu S, Katoh S, Nishi N, Takeshita K, Niki T, Tominaga A, Yamauchi A and Hirashima M: Galectin-9 suppresses tumor metastasis by blocking adhesion to endothelium and extracellular matrices. Glycobiology 18: 735-744, 2008

62. Kadowaki T, Arikawa T, Shinonaga R, Oomizu S, Inagawa H, Soma G, Niki T and Hirashima M: Galectin-9 signaling prolongs survival in murine lung-cancer by inducing macrophages to differentiate into plasmacytoid dendritic cell-like macrophages. Clin Immunol 142: 296-307, 2012.

63. Danguy A, Camby I and Kiss R: Galectins and cancer. Biochim Biophys Acta 1572: 285-293, 2002

64. Cheng DE, Chang WA, Hung JY, Huang MS and Kuo PL: Involvement of IL10 and granulocyte colonystimulating factor in the fate of monocytes controlled by galectin-1. Mol Med Rep 10: 2389-2394, 2014

65. Kuo PL, Huang MS, Cheng DE, Hung JY, Yang CJ and Chou SH: Lung cancer-derived galectin-1 enhances tumorigenic potentiation of tumor-associated dendritic cells by expressing heparin-binding EGF-like growth factor. J Biol Chem 287: 9753-9764, 2012 .

66. Schulkens IA, Heusschen R, van den Boogaart V, van Suylen RJ, Dingemans AM, Griffioen AW and Thijssen VL: Galectin expression profiling identifies galectin-1 and Galectin-9 $\Delta 5$ as prognostic factors in stage I/II non-small cell lung cancer. PLoS One 9: e107988, 2014.

67. Carlini MJ, Roitman P, Nuñez M, Pallotta MG, Boggio G, Smith D, Salatino M, Joffé ED, Rabinovich GA and Puricelli LI: Clinical relevance of galectin-1 expression in non-small cell lung cancer patients. Lung Cancer 84: 73-78, 2014.

68. Kuo P, Bratman SV, Shultz DB, von Eyben R, Chan C, Wang Z, Say C, Gupta A, Loo BW Jr, Giaccia AJ, et al: Galectin-1 mediates radiation-related lymphopenia and attenuates NSCLC radiation response. Clin Cancer Res 20: 5558-5569, 2014.

69. Mathieu A, Saal I, Vuckovic A, Ransy V, Vereerstraten P, Kaltner H, Gabius HJ, Kiss R, Decaestecker C, Salmon I and Remmelink M: Nuclear galectin-3 expression is an independent predictive factor of recurrence for adenocarcinoma and squamous cell carcinoma of the lung. Mod Pathol 18: 1264-1271, 2005.

70. Wang T, Chu Z, Lin H, Jiang J, Zhou X and Liang X: Galectin-3 contributes to cisplatin-induced myeloid derived suppressor cells (MDSCs) recruitment in Lewis lung cancer-bearing mice. Mol Biol Rep 41: 4069-4076, 2014.

71. Wu SW, Yu L, Zhou L, Cheng ZN and Tao YS: Expression of Gal-3 and CD82/KAI1 proteins in non-small cell lung cancer and their clinical significance. Zhonghua Zhong Liu Za Zhi 35: 124-128, 2013 (In Chinese).

72. Huflejt ME and Leffler H: Galectin-4 in normal tissues and cancer. Glycoconj J 20: 247-255, 2004

73. Rumilla KM, Erickson LA, Erickson AK and Lloyd RV: Galectin-4 expression in carcinoid tumors. Endocr Pathol 17: 243-249, 2006.

74. Zhu H, Pei HP, Zeng S, Chen J, Shen LF, Zhong MZ, Yao RJ and Shen H: Profiling protein markers associated with the sensitivity to concurrent chemoradiotherapy in human cervical carcinoma. J Proteome Res 8: 3969-3976, 2009.

75. Biron-Pain K, Grosset AA, Poirier F, Gaboury L and St-Pierre Y: Expression and functions of galectin-7 in human and murine melanomas. PLoS One 8: e63307, 2013.

76. Caulet-Maugendre S, Birolleau S, Corbineau H, Bassen R, Desrues B, Bidon N, Delaval P, Ramée MP, Brichory F and Dazord L: Immunohistochemical expression of the intracellular component of galectin- 8 in squamous cell metaplasia of the bronchial epithelium in neoplastic and benign processes. Pathol Res Pract 197: 797-801, 2001.

77. Gopalkrishnan RV, Roberts T, Tuli S, Kang D, Christiansen KA and Fisher PB: Molecular characterization of prostate carcinoma tumor antigen-1, PCTA-1, a human galectin- 8 related gene. Oncogene 19: 4405-4416, 2000. 
78. Bassen R, Brichory F, Caulet-Maugendre S, Bidon N, Delaval P, Desrues B and Dazord L: Expression of Po66-CBP, a type-8 galectin, in different healthy, tumoral and peritumoral tissues. Anticancer Res 19: 5429-5433, 1999.

79. Bidon-Wagner $N$ and Le Pennec JP: Human galectin- 8 isoforms and cancer. Glycoconj J 19: 557-563, 2002.

80. Henno S, Brichory F, Langanay T, Desrues B, Bidon N, Delaval P, Ramee MP, Dazord L and Caulet-Maugendre S: Expression of Po66-CBP, a galectin-8, in different types of primary and secondary broncho-pulmonary tumors. Oncol Rep 9: 177-180, 2002.

81. Dazord L, Bourel D, Martin A, Lecorre R, Bourguet P, Bohy J, Saccavini JC, Delaval P, Louvet M and Toujas L: A monoclonal antibody (Po66) directed against human lung squamous cell carcinoma immunolocalization of tumour xenografts in nude mice. Cancer Immunol Immunother 24: 263-268, 1987.
82. Nagahara K, Arikawa T, Oomizu S, Kontani K, Nobumoto A Tateno H, Watanabe K, Niki T, Katoh S, Miyake M, et al: Galectin-9 increases Tim- $3^{+}$dendritic cells and CD8 ${ }^{+} \mathrm{T}$ cells and enhances antitumor immunity via galectin-9-Tim-3 interactions. J Immunol 181: 7660-7669, 2008.

83. Perillo NL, Marcus ME and Baum LG: Galectins: Versatile modulators of cell adhesion, cell proliferation and cell death. J Mol Med (Berl) 76: 402-412, 1998.

84. Hughes RC: Galectins as modulators of cell adhesion. Biochimie 83: 667-676, 2001.

85. Heinrich EL, Walser TC, Krysan K, Liclican EL, Grant JL, Rodriguez NL and Dubinett SM: The inflammatory tumor microenvironment, epithelial mesenchymal transition and lung carcinogenesis. Cancer Microenviron 5: 5-18, 2012.

86. Tsai MJ, Chang WA, Huang MS and Kuo PL: Tumor microenvironment: A new treatment target for cancer. ISRN Biochem 2014: 351959, 2014. 